\section{Evaluation of families derived from backcrosses of processed tomato with dwarfism gene}

\author{
Pedro Yuri Cavasin ${ }^{1 *}$, Leandro Augusto Andrade Fumes ${ }^{1}$, \\ Andressa Rodrigues Fonseca ${ }^{1}$ and Derly José Henriques da Silva ${ }^{1}$
}

\begin{abstract}
In comparison to tomato plants without the dwarfism gene, dwarf tomato plants were shorter, had a smaller canopy diameter and remained upright during maturation, thereby reducing the fruit-soil contact, resulting in healthier fruits. This study evaluated tomato families of $a B C_{1} F_{3}$ population carrying the dwarf gene for industrial yield. The $150 B C_{1} F_{3}$ families and the two parents (hybrid $\mathrm{H}-9889$ and accession $\mathrm{BGH}-9889$ ) as controls were assessed in an augmented block design with four replications. The data were subjected to variance analysis and the F test. A selection index, based on the sum of ranks of Mulamba and Mock (1978), was used for the selection of genotypes, considering the most relevant traits, i.e., canopy diameter, yield, lodging and fruit firmness. Thus, selection resulted in a yield gain of $8.04 \%$.
\end{abstract}

Keywords: Breeding, dwarf, Solanum lycopersicum.

\section{INTRODUCTION}

Tomato (Solanum lycopersicum L.) is considered one of the most important vegetables since it is not only used fresh, but also for industrial processing. The center of diversity of this herbaceous plant of the family Solanaceae is in South America, more precisely in the Andes, where the main domestication center lies between northern Chile and Ecuador. Another possible center of diversity is Mexico (Dupin et al. 2017, Palchetti et al. 2020).

The main countries producing processed tomato are the United States, Italy, China, Spain and Brazil (WPTC 2021). In Brazil, the states of Goiás, São Paulo, and Minas Gerais have the largest areas of tomato cultivation and produce high quantities for industrial processing (IBGE 2017). The increase in tomato yields in recent years was due to the favorable cultivation conditions in the cerrado region (Goiás and Minas Gerais), where mechanical operations can be used more intensely, facilitating e.g., transplanting and harvesting (Peixoto et al. 2017a, Silva et al. 2018, Almeida Neta et al. 2020). It is commonly acknowledged that hybrids and commercial lines should have: a) a high yield potential, b) concentrated maturation period, c) long durability of mature fruits on the plant, d) multiple disease resistance, e) a good canopy cover, f) smaller fruits (SST), and g) higher flesh firmness (Peixoto et al. 2017a, Peixoto et al. 2017b). The key challenge for Brazilian seed industries is to develop hybrids with these traits in breeding programs (Zeist et al. 2018).

In spite of the increase in processed tomato production, the Brazilian output does not meet domestic consumption, requiring imports of processed tomato
Crop Breeding and Applied Biotechnology 21(1): e362221113, 2021 Brazilian Society of Plant Breeding. Printed in Brazil http://dx.doi.org/10.1590/1984$70332021 v 21 n 1 n 13$

70332021v21n1n13 \title{
.
}




\section{PY Cavasin et al.}

from other countries, e.g., Argentina, Italy, the United States and especially Chile and China. One of the strategies to make tomato production economically more sustainable is the modification of the plant morphology to raise the yield efficiency and/or harvesting efficiency. Breeding for dwarfism is a strategy that can be exploited by researchers to adjust different crops to a particular cropping system and increase their productivity, without losses with regard to other traits.

The most famous case of the use of dwarfism in plants is that of wheat. The development of dwarf or semi-dwarf wheat cultivars allowed an increase in planting density and fertilization without the occurrence of lodging, thereby indirectly increasing productivity (Camargo 1984). Apart from wheat, a reduced plant size proved beneficial in the case of other crops as well. For rice and barley, the main advantage was a reduction in lodging, resulting, indirectly, in higher productivity (Bierbiger 1968, Rutger and Peterson 1976).

Several studies addressed the introgression of dwarfism genes into tomato, but most of them focused on the exploitation of dwarfism for the development of ornamental cultivars (Gerszberg el al. 2015, Yoshihiro and Tohru 2016). The dwarfism genes used in these cultivars usually lead to extremely small plants with a short cycle, intended for pot cultivation. Moreover, due to the ease of cultivation and the short cycle, these cultivars have also been widely used in studies of genetic transformation (Maciel et al. 2015).

Studies on the exploitation of dwarfism in cultivars for fruit production were also carried out. According to Finzi et al. (2017), dwarf lines planted at high densities were more productive than normal-sized cultivars. Yanokuchi and Okamoto (2001) evaluated different sources of dwarfism used in the breeding of cherry tomatoes. They recommended the use of the bu gene, due to the possibility of early identification of dwarf progenies, and found a higher fruit yield per plant. More compact plants, i.e., with shorter leaf and internode length, should be one of the objectives of breeding for processed tomato since such plants are better suited for mechanical harvesting (Finzi et al. 2017, Martínez-Gómez 2019, Finzi et al. 2020).

To remain competitive, tomato breeding programs for industrial processing should develop the agronomic traits of compact and small plants with concentrated fruit maturation, facilitating mechanical harvesting, and mainly with higher yields and improved disease resistance (Sun et al. 2019).

Fungi such as Rhizoctonia solani, Sclerotium rolfsii, Sclerotinia sclerotiorum and Alternaria solani are some of the main causes of damage on fruit in contact with wet soils (Grigolli et al. 2011, Ozkaya and Ergun 2017). Thus, the introgression of the dwarf gene into tomato for industrial processing can decrease the fruit quality loss at harvest by reducing the entry of soil particles into the tomato harvesting machine, and since the plants will stand upright for a longer time, thus reducing the time of fruit-soil contact (Sun et al. 2019).

Adequate fruit firmness confers resistance to damage during transportation, where tomato is currently handled entirely in bulk. Soft fruits, particularly those with low firmness, are more prone to deformation and to the rupture of the pericarp, leading to the release of cell juice and fermentation and deterioration during transportation from the field to the processing industry. Aside from the genetic factors, the effects of plant nutrition, soil water availability and maturation stage also affect this trait. The fruits must have a thick and firm pericarp and a compact pulp without any empty spaces (Clemente and Boiteux 2012).

The selection of genotypes with high fruit firmness is a rather challenging task, since a high number of genes are involved in the trait expression (Gerszberg et al. 2015, Li et al. 2020). In fact, in a study of Aragão et al. (2004), no difference was observed between experimental and commercial hybrids, indicating the difficulty of selecting superior genotypes.

Producers of tomato for industrial processing are not only in search for cultivars with a series of essential traits regarding field yield and industrial quality, but also with high yields. To this end, yield-related components must be studied to contribute as much as possible to yield optimization, without losing the industrial as well as the physical fruit quality. The objective of this study was to identify families of a $\mathrm{RC}_{1} \mathrm{~F}_{3}$ tomato population for industrial processing that carry the dwarf gene, with potential for breeding superior lines.

\section{MATERIAL AND METHODS}

This field experiment was carried out in Viçosa-Minas Gerais, on an experimental field (lat $20^{\circ} 45^{\prime} 14^{\prime \prime} \mathrm{S}$, long $42^{\circ}$ $52^{\prime} 53^{\prime \prime} \mathrm{W}$ and alt $648 \mathrm{~m}$ asl) of the Agronomy Department of the Federal University of Viçosa (DAA/UFV). Yield and 
morpho-agronomic traits were evaluated at the experimental location, while the industrial fruit quality was assessed in the Laboratory of Management of Plant Genetic Resources of the DAA/UFV. The soil of the experimental field was prepared by plowing, disking and furrowing. Fertilization, based on soil chemical analysis, was applied according to official recommendations for the crop (Ribeiro 1999) during soil tillage and by fertigation.

The seedlings were grown in a greenhouse, in polystyrene trays with 128 cells, filled with commercial substrate. The seedlings were transplanted to the field in the 4-5 leaf stage, approximately 30 days after sowing. Cultural practices and phytosanitary treatments were applied according to the crop requirements (Clemente and Boiteux 2012). Irrigation was applied as needed. The plants were grown on the ground, in other words, not on a trellis.

Hybrids were derived from a partial diallel cross between the commercial hybrids: UG 8169 (Agristar); HMX 7889 (Agrising); H 9553 (Heinz); AP 533 (Seminis); H 9992 (Heinz); H 9889 (Heinz); N 901 (Nunhens); and U 2006 (Nunhens) with accessions of dwarf-sized tomato of the vegetable germplasm bank, Federal University of Viçosa (BGH-UFV), namely BGH-1989, BGH-2006, BGH-2077 and BGH-2086. These accessions were chosen due to the dwarf size of the plant, i.e. they have a dwarf gene that confers this phenotype, without reducing the fruit size. The accessions, aside from having different morphological characteristics, generate great genetic variability. The $F_{1}$ hybrids were selected based on the general combining ability (GCA) (Griffing 1956, Cruz et al. 2012), according to the ranking of the traits for processed tomato, defined here: fruit yield, total soluble solids content, firmness, titratable acidity, and pH. The cross ' $\mathrm{H} 9889 \times \mathrm{BGH}$ 2006' was then selected as the most promising to breed populations with dwarf plants and fruits suited for processing.

To increase the frequency of favorable genes in the population, a backcross was performed after the initial cross (partial diallel), using $\mathrm{F}_{1}$ plants as female and the commercial hybrid as male parents, to produce the $\mathrm{RC}_{1} \mathrm{~F}_{1}$ seeds. A total of 600 plants were sown and the dwarf phenotypes were selected in the tray phase, i.e., $25 \%$ or 150 plants. The seeds of the selected plants were extracted separately (seeds $R C_{1} F_{3}$ ). To initiate the families, five $R C_{1} F_{3}$ plants of each $R C_{1} F_{2}$ plant were evaluated in an Augmented Block Design (ABD), with four replications. The parents were used as checks (H-9889 and BGH-2006). In the ABD, different from a randomized block design, only the checks are repeated, so that a higher number of genotypes can be tested in a smaller area.

For all evaluations, the data were measured separately per plant and the following morphological traits were evaluated: a) canopy diameter (averaging the distances between three canopy extremities, measured with a tape, in $\mathrm{cm}$ ); and b) lodging (1-5 score scale; 1 - upright plants and 5 - fully lodged). Yield traits was estimated by the fruits yield per plant (weighed on an analytical balance, in $\mathrm{kg} \mathrm{plant}^{-1}$ ). Fruit quality was determined in a three-fruit-sample by the fruit firmness (using a digital penetrometer with a $4 \mathrm{~mm}$ diameter probe, model PTR-300, in N).

The data were subjected to variance analysis and to the $\mathrm{F}$ test to determine significance $(\alpha \leq 0.05)$. From the resulting data, the genetic parameters genotypic variance, environmental variance and heritability were estimated. Heritability was calculated by dividing the genotypic by the phenotypic variance. The selection index, based on the sum of ranks of Mulamba and Mock (1978), was used for a selection of genotypes by taking all traits into consideration that were significant by the $\mathrm{F}$ test $(\alpha \leq 0.05)$.

\section{RESULTS AND DISCUSSION}

In the analysis of variances, the traits tomato yield, canopy diameter, plant lodging and fruit firmness were significant $(\alpha \leq 0.05)$ by the $F$ test, indicating variability among families, thereby allowing the selection of the best ones. Further, the selection gains (SG\%) by direct selection were estimated for these traits, to indicate possible gains in the others (Table 1). However, by this method, regardless of the selected trait, at a selection intensity of $10 \%$ (15 families), losses occurred for at least one of the traits. It is worth remembering that negative SG (\%) values for lodging and canopy diameter are desirable, since the target values for these traits are lower due to dwarfism.

Alternatively, the ranking index based on the sum of ranks of Mulamba and Mock (1978) allows the use of economic weight for the traits. In several simulations of economic weights, the following proportion was found to be most adequate: 3 fruit yield: 3 canopy diameter: 2 lodging: 4 firmness, i.e., prioritizing firmness as determinant factor of fruit quality (Table 2). The trait fruit yield is essential, but the economic weight was equivalent to that of canopy diameter. A shorter canopy diameter and reduced lodging improve the fruit quality and reduce the fruit damage in the tomato harvesting 
Table 1. Direct selection for four traits of $\mathrm{RC}_{1} \mathrm{~F}_{3}$ tomato families with dwarfism gene to select plants with optimized genetic contribution

\begin{tabular}{|c|c|c|c|c|c|c|c|}
\hline \multirow{2}{*}{ Direct Selection } & \multirow[b]{2}{*}{$x_{0}$} & \multirow[b]{2}{*}{$h^{2}$} & & \multicolumn{4}{|c|}{ Response in traits } \\
\hline & & & & Yield & Canopy D. & Lod. & Fir. \\
\hline \multirow{3}{*}{$\begin{array}{l}\text { Yield } \\
\left(\text { kg plant }^{-1}\right)\end{array}$} & & & Xs & $3,864.6$ & 69.68 & 3.65 & 13.27 \\
\hline & $2,514.2$ & 92.3 & SD & $1,332.4$ & 11.78 & 0.94 & -1.04 \\
\hline & & & SG (\%) & 49.58 & 19.3 & 31.33 & -6.74 \\
\hline \multirow{2}{*}{$\begin{array}{l}\text { Canopy diameter } \\
(\mathrm{cm})\end{array}$} & & & Xs & $1,667.9$ & 40.83 & 1.76 & 15.75 \\
\hline & 57.90 & 94.9 & SD & -846.3 & -17.07 & -0.95 & 1.44 \\
\hline \multirow[t]{2}{*}{ Lodging } & 2.71 & 89.9 & SD & -403.7 & -9.46 & -1.55 & -0.54 \\
\hline & & & SG (\%) & -14.82 & -15.51 & -51.39 & -3.51 \\
\hline \multirow{3}{*}{$\begin{array}{l}\text { Firmness } \\
\text { (N) }\end{array}$} & & & Xs & $2,142.9$ & 56.76 & 2.85 & 21.18 \\
\hline & 14.31 & 93.3 & SD & -371.3 & -1.14 & 0.14 & 6.87 \\
\hline & & & SG (\%) & -13.63 & -1.87 & 4.77 & 44.84 \\
\hline
\end{tabular}

$\mathrm{X}_{\mathrm{o}}$ : population mean; $\mathrm{h}^{2}$ : heritability; Canopy D.: canopy diameter; Lod.: Lodging; Fir.: Firmness; $\mathrm{Xs:}$ Selected mean; SD: Selection differential; SG: selection gain (\%).

Table 2. Selection indices of Mulamba and Mock (1978) for selected traits of $R C_{1} F_{3}$ tomato families carrying the dwarfism gene, to select plants with optimized genetic contribution

\begin{tabular}{|c|c|c|c|c|c|}
\hline Traits & EcW & $x_{0}$ & Xs & SG\% & H9889 \\
\hline Yield per plant (g) & 3 & 2,514 & 1,951 & -20.64 & 3,724 \\
\hline Canopy diameter $(\mathrm{cm})$ & 3 & 57.90 & 45.21 & -20.79 & 82 \\
\hline Lodging & 2 & 2.71 & 1.49 & -40.47 & 5 \\
\hline Firmness (N) & 4 & 14.30 & 19.38 & 33.16 & 18.06 \\
\hline Yield $\left(\mathrm{t} \mathrm{ha}^{-1}\right)$ & & & 49.06 & & 45.41 \\
\hline
\end{tabular}

EcW: Economic weight; $X_{2}$ : Population mean; Xs: Selected mean; SG: selection gain (\%); H9989: Values of the commercial hybrid; Canopy diameter, scored on a scale.

machine, but also allow a higher planting density, thereby compensating the reduction in yield per plant by an increase in productivity per area.

When comparing the values of economic weights of the selected families with the hybrid data (Table 2), a reduction in canopy diameter of $55.13 \%$, a reduction in lodging of $72 \%$, an increase in fruit firmness of $7.30 \%$ and a decrease in yield of $47.58 \%$ were observed. However, when increasing plant density, in an area of $0.82 \mathrm{~m}^{2}$, previously required for one plant, 1.81 plants can be grown, thus increasing the productivity by 3.65 tons ha ${ }^{-1}(8.04 \%)$.

For the selection of superior families, higher values of genetic parameters such as heritability and genotypic variance are of great interest. When using the parents mentioned above, plants with significant gains could be selected for the traits canopy diameter, plant lodging as well as fruit firmness.

\section{ACKNOWLEDGMENTS}

The authors thank the Research Foundation of the State of Minas Gerais (Fapemig), Brazilian Federal Agency for Support and Evaluation of Graduate Education (Capes), and the National Council for Scientific and Technological Development (CNPq) for funding.

\section{REFERENCES}

Almeida Neta MN, Mota WFD, Pegoraro RF, Pacheco MC, Batista CM and Soares MDC (2020) Agronomic yield and quality of industrial tomatoes under NPK doses. Revista Brasileira de Engenharia Agrícola e Ambiental 24: 59-64.

Aragão FA, Giordano LdB, Melo PC and Boiteux LS (2004) Desempenho de híbridos experimentais de tomateiro para processamento industrial nas condições edafo-climáticas do cerrado brasileiro. Horticultura Brasileira 22: 529-533.

Bierbiger A (1968) The creation of semi-dwarf barley varieties. Euphytica 17: $177-184$.

Camargo CEDO (1984) Melhoramento do trigo. IX. Estudo genético de fontes de nanismo. Bragantia 43: 591-603. 
Evaluation of families derived from backcrosses of processed tomato with dwarfism gene

Clemente FMVT and Boiteux LS (2012) Produção de tomate para processamento industrial. Embrapa, Brasília, 344p.

Cruz CD, Regazzi AJ and Carneiro PCS (2012) Modelos biométricos aplicados ao melhoramento genético. UFV, Viçosa, 514p.

Dupin J, Matzke NJ, Särkinen T, Knapp S, Olmstead RG, Bohs L and Smith SD (2017) Bayesian estimation of the global biogeographical history of the Solanaceae. Journal of Biogeography 44: 887-899.

Finzi RR, Maciel GM, Peres HG, Silva MF, Peixoto JVM and Gomes DA (2020) Agronomic potential of $B C_{1} F_{2}$ dwarf round tomato populations. Ciência e Agrotecnologia 44: 1-8.

Finzi RR, Maciel GM, Silva ECD, Luz JMQ and Borba MEA (2017) Agronomic performance of mini-tomato hybrids from dwarf lines. Ciência e Agrotecnologia 41: 15-21.

Gerszberg A, Hnatuszko-Konka K, Kowalczyk T and Kononowicz AK (2015) Tomato (Solanum lycopersicum L.) in the service of biotechnology. Plant Cell, Tissue and Organ Culture 120: 881-902.

Griffing B (1956) Concept of general and specific combining ability in relation to diallel crossing systems. Australian Journal of Biology Science 9: 463-493.

Grigolli JFJ, Kubota MM, Alves DP, Rodrigues GB, Cardoso CR, Silva DJHD and Mizubuti ESG (2011) Characterization of tomato accessions for resistance to early blight. Crop Breeding and Applied Biotechnology 11: $174-180$.

IBGE - Instituto Brasileiro de Geografia e Estatística (2017) Levantamento sistemático da produção Agrícola: pesquisa mensal de previsão e acompanhamento das safras agrícolas no ano civil. Fundação Instituto Brasileiro de Geografia e Estatística 30: 1-81.

Li R, Sun S, Wang H, Wang K, Yu H, Zhou Z, Xin P, Chu J, Zhao T, Wang H, Li J and Cui X (2020) FIS1 encodes a GA2-oxidase that regulates fruit firmness in tomato. Nature Communications 11: 1-12.

Maciel G, Silva ECD and Fernandes MAR (2015) Ocorrência de nanismo em planta de tomateiro do tipo grape. Revista Caatinga 28: 259-264.

Martínez-Gómez P (2019) Editorial for special issue "Plant genetics and molecular breeding". International Journal of Molecular Sciences 20: 1-5.

Mulamba NN and Mock JJ (1978) Improvement of yield potential of the Eto Blanco maize (Zea mays L.) population by breeding for plant traits. Egyptian Journal of Genetics and Cytology 7: 40-57.

Ozkaya HO and Ergun T (2017) The effects of Allium tuncelianum extract on some important pathogens and total phenolic compounds in tomato and pepper. Paquistão Journal of Botany 49: 2483-2490.

Palchetti MV, Barboza GE and Cantero JJ (2020) Solanaceae diversity in South America and its distribution in Argentina. Anais da Academia Brasileira de Ciências 92: 1-17.

Peixoto JMV, Cardoso AF, Lana RMQ and Nascimento ADR (2017a) Establishing diagnosis and recommendation integrated system (DRIS) for industrial use of tomato. Australian Journal of Crop Science 11: 193-198.

Peixoto JVM, Neto CM, Campos LF, Dourado WDS, Nogueira AP and Nascimento AD (2017b) Industrial tomato lines: morphological properties and productivity. Genetics and Molecular Research 16: 1-15.

Ribeiro AC (1999) Recomendações para o uso de corretivos e fertilizantes em Minas Gerais: 5. Aproximação. Comissão de Fertilidade do Solo do Estado de Minas Gerais/Editora UFV, Viçosa, 323p.

Rutger J and Peterson M (1976) Improved short stature rice. California Agriculture 30: 4-6.

Silva CJ, Pontes NC, Golynski A, Braga MB and Quezado-Duval AM and Silva NE (2018) Performance of processing tomatoes under different supply levels of crop evapotranspiration. Horticultura Brasileira 36: 299-305.

Sun X, Shu J, Ali Mohamed AM, Deng X, Zhi X, Bai J, Cui Y, Lu X, Du Y, Wang X, Huang Z, Guo Y, Liu L and Li J (2019) Identification and characterization of El (Elongated Internode) gene in tomato (Solanum lycopersicum). International Journal of Molecular Sciences 20: 1-18.

WPTC - The Word Processing Tomato Council (2021) World production estimate of tomatoes for processing 2019 FINAL (in 1000 metric tonnes). Available at <https://www.wptc.to/pdf/releases/WPTC\%20 world\%20production $\% 20$ estimate $\% 20$ as\%20 of \%2012\%20 February\%202019.pdf> Accessed on January 10, 2021.

Yanokuchi Y and Okamoto K (2001) Varietal difference in internode length of tomato and inheritance and adaptability to tomato cultivation of the short-internode character. Bulletin of the Nagano Chushin Agricultural Experiment Station 16: 17-28.

Yoshihiro O and Tohru A (2016) Mutant resources and TILLING platforms in tomato research. In Ezura H, Ariizumi T, Garcia-Mas J and Rose J (eds) Functional genomics and biotechnology in solanaceae and cucurbitaceae crops. Springer, New York, p. 75-92.

Zeist AR, Resende JT, Faria MV, Gabriel A, Adriano E and Lima-Filho RB (2018) Photosynthetic characteristics in species and interspecific hybrids of tomato. Horticultura Brasileira 36: 362-370.

(cc) EY This is an Open Access article distributed under the terms of the Creative Commons Attribution License, which permits unrestricted use, distribution, and reproduction in any medium, provided the original work is properly cited. 